\title{
PATENT POLICY AND PREEMPTION: THE STIFFEL AND COMPCO CASES
}

\author{
James M. Treece†
}

I N January 1956, the Stiffel Company, a manufacturer of lamps for home use, added to its merchandise line a pole lamp-a decorative tube extending from floor to ceiling, held in place by a compression spring at one end, and having lamp fixtures along the outside. Soon after, Stiffel Company applied to the federal government for a mechanical patent and a design patent on this lamp. In August 1956, Sears, Roebuck and Company contracted with its supplier for lamps which were exact copies of Stiffel's pole lamp and which were marketed without identifying markings. The Sears copy retailed at roughly the wholesale price of its rival.

After receiving mechanical and design patents on its lamp, Stiffel sued for patent infringement and unfair competition. The district court ruled that both patents were invalid because they were anticipated by and lacked invention over the prior art, but held that Sears, in making a substantially exact copy of the Stiffel product, was guilty of unfair competition under Illinois law. The court enjoined Sears from thereafter selling or attempting to sell pole lamps identical to or confusingly similar to Stiffel's lamp. ${ }^{1}$

The Seventh Circuit affirmed, ${ }^{2}$ noting that the Sears and Stiffel lamps "have a remarkable sameness of appearance" 3 and that the finding below that Sear's copying caused "customer confusion" was intended to refer to confusion as to "the source of the lamps" and was not clearly erroneous. 4

The Supreme Court, in two opinions by Mr. Justice Black, reversed the Seventh Circuit without dissent in Sears, Roebuck \& Co. v. Stiffel Co., ${ }^{5}$ and its companion case, Compco Corp. v. Day-Brite Lighting, Inc. ${ }^{6}$

$\dagger$ Assistant Professor of Law, Rutgers University.

1 The district court's judgment was rendered on January 22, 1962; its findings of fact and conclusions of law are unreported. The foregoing statement of facts was taken from Petitioner's Brief, Respondent's Brief and Brief for the United States as Amicus Curiae, Sears Roebuck \& Co. v. Stiffel Co., 376 U.S. 225 (1964).

2 Stiffel Co. v. Sears Roebuck \& Co., 313 F.2d 115 (7th Cir. 1963), rev'd, 376 U.S. 225 (1964).

$3 I d$. at 118.

4 Id. at 118 , nn.6, 7 .

5376 U.S. 225 (1964).

6376 U.S. 234 (1964). The defendant in the Compco case copied a lighting reflector on a fluorescent lighting fixture marketed by plaintiff, Day-Brite Lighting, Inc. DayBrite sued for design patent infringement and unfair competition. The same district 
The opinion in Stiffel first stated that Congress was expressly empowered by the Constitution to make provisions for patents and copyrights, ${ }^{7}$ and then inferred from the exclusive jurisdiction of the federal courts over patents and copyrights that Congress intended a policy of national uniformity to prevail. ${ }^{8}$ But, the opinion continued, even if Congress has not by legislation denied to the states the power to regulate directly or indirectly in the sphere of Congress' competence under the patent clause of the Constitution, the supremacy clause requires that even state law evolved in the exercise of undoubted state power must fall if it comes in conflict with valid federal law or policy. In short, if Illinois law was applied in the case at hand to suspend rights insured by the federal patent laws, then the application could not stand even if within Illinois' power absent the conflict.

Conflict was found, since federal patent law was regarded as granting the public a right to make any article first made by another if the article cannot qualify for patent protection for lack of invention or if the limited period of patent protection has expired. By preventing copying, Illinois law limited a right conferred on the public by federal law.

To allow a State by use of its law of unfair competition to prevent the copying of an article which represents too slight an advance to be patented would be to permit the State to block off from the public something which federal law has said belongs to the public. The result would be that while federal law grants only 14 or 17 years' protection to genuine inventions... States could allow perpetual protection to articles too lacking in novelty to merit any patent at all under federal Constitutional standards. This would be too great an encroachment on the federal patent system to be tolerated. ${ }^{9}$

Had the Court secured to Stiffel and Day-Brite an exclusive right in their product configurations, it would have created a source of economic

court which decided the Stiffel case held that the design patent was invalid but enjoined Compco Corporation from unfairly competing with the patentee by the sale of identical or nearly similar reflectors. The Seventh Circuit affirmed, saying, "The capacity of the plaintiff's design to serve the plaintiff in somewhat the manner of a trademark does constitute a 'protectable' right." 311 F.2d 26, 30 (7th Cir. 1962), rev'd, 376 U.S. 234 (1964). The record in this was slightly stronger on the point of confusion about source than was the record in the Stiffel case, but not significantly stronger. In Stiffel there was no evidence that anyone who cared was confused about source by Sears' copying, while in Compco there was evidence of some confusion about source in the trade, a type of confusion which is legally insignificant according to general principles of unfair competition law. Classifying the cases as indistinguishable on their records seems reasonable.

7376 U.S. 225, 228 (1964).

$8 \mathrm{Id}$. at $231, \mathrm{n} .7$.

- 376 U.S. 225, $231-32$. 
power in them, ${ }^{10}$ by allowing them to escape competition from identical products. $^{11}$ For example, Stiffel Company's control over supply and price, as the only seller of particular types of pole lamps, would be limited only by the willingness of consumers to substitute other types of lamps. ${ }^{12}$ The Court thus declined to protect a theoretically anti-competitive means of product differentiation. ${ }^{13}$ But some commentators protest that the competitive mechanism requires encouraging sellers to differentiate their products. ${ }^{14}$ Unless consumers can distinguish competing goods, it is argued, factors inducing consumer preference cannot be isolated. ${ }^{15}$

The policy announced by the Court struck a balance between the opposing views. ${ }^{16}$ While it is reasonable to assume that one way consumers could identify Stiffel's pole lamp before Sears entered the market was by its design and over-all appearance, and while it seems clear that the certainty of that means of source identification was reduced materially when the Court sustained Sears' right to copy, it is indisputably clear that these decisions did not free competitors to copy all means of product differentiation. In the words of the Court:

Doubtless a State may, in appropriate circumstances, require that goods whether patented or unpatented, be labeled or that other precautionary steps be taken to prevent customers from being misled as to the source, just as it may protect businesses in the use of their trademarks, labels, or distinctive dress in the packaging of goods so as to prevent others, by imitating such markings, from misleading purchasers as to the source of the goods. ${ }^{17}$

10 See, e.g., Bain, Barriers to New Competrtion 115-16 (1956). Cf. Cohen, Transcendental Nonsense and the Functional Approach, 35 CoLum. L. Rev. 809, 816 (1935).

11 Cf. Eastern Wine Corp. v. Winslow-Warren, Ltd., 137 F.2d 955, 957 (2d Cir. 1943) (Frank, J.).

12 See Olson \& McFarland, The Restoration of Pure Monopoly and the Concept of Industry, 76 Q.J. ECON. 613, 620-22 (1962).

13 See McConnell \& Peterson, Diversification and Differentiation in Small Manufacturing Firms: An Empirical Study, Q. REv. Econ. \& Bus., Spring 1964, pp. 29-31.

14 Pattishall, Trade-Marks and the Monopoly Phobia, 50 Mich. L. REv. 967 (1952). As to the modes of differentiating products, see generally Chamberlin, The Theory of Monopolistic Comperrtion 56 (7th ed. 1956); Chamberlin, Product Heterogeneity and Public Policy, 40 Am. Econ. Rev. 85, 86 (Pt. 2 1950).

15 See Rogers, The Lanham Act and the Social Function of .Trademarks, 14 LAw \& ConteMr. Prob. 173, 180-82 (1949).

16 See Greenhut, Free Entry and the Trade Mark-Trade Name Protection, 24 So. ECoN. J. 170, 178-81 (1957), for an interesting proposal regarding the standard to be employed by courts in balancing the desirability of protecting means by which consumers identify source against the desirability of unfettering competitors in their efforts to encroach upon first comers' immunities from competitive forces.

17 Sears Roebuck \& Co. v. Stiffel Co., 376 U.S. 225, 232 (1964). 
The incapacity of Illinois law to protect the Day-Brite and Stiffel product configurations was grounded upon federal preemption. The extent to which this preemption theory will affect areas previously regarded as within the competence of the states may turn in part upon whether the disability is viewed as imposed by negative implications from the patent clause or by the operation of the supremacy clause upon situations where state law conflicts with the federal statutory patent policy.

The patent clause empowers Congress "To promote the Progress of Science and useful Arts, by securing for limited Times to Authors and Inventors the exclusive Right to their respective Writings and Discoveries."18 Authority for implying from this grant of power an exclusion of state competence is perhaps limited to Learned Hand's much discussed dissent in Capital Records, Inc. v. Mercury Records Corp., ${ }^{10}$ where Hand was speaking only of "writings" and not "discoveries." Even there, Hand's thesis was a narrow one: that the limited times phrase prevents a state from granting a perpetual monopoly in a published work. But as has been well noted by Kalodner and Vance, ${ }^{20}$ a theory of constitutional preemption is not without difficulties. To suggest that the constitutional phrase prohibits state protection of "unpublished" works defies well-established principles of common law copyright. Yet nowhere in the language of the phrase is there a reason for distinguishing federal preemption of published works from unpublished works. Indeed, the distinction based upon publication is one based upon use, not time, and the policy expressed by the constitutional language is that of protection for "limited times" without reference to use. Furthermore, once the limited times phrase is regarded as restricting state power, similar logic would seem to require interpreting the terms "writings," "authors," "inventors" and "discoveries" as limitations on state power.

The question of state competence in the patent field came up early in connection with grants by New York of "patent" rights in steamboat transportation to potential and actual inventors. The question of the compatibility of the New York grant with the patent power of the federal

18 U.S. Const., Art. I, § 8.

19221 F.2d 657, 664 (2d Cir. 1955) (Hand, J., dissenting). See Kaplan, Performer's Right and Copyright: The Capitol Records Case, 69 HARv. L. REv. 409 (1956); Kaplan, Publication in Copyright Law: The Question of Phonograph Records, 103 U. PA. L. REv. 469 (1955); Kalodner \& Vance, The Relation Between Federal and State Protection of Literary and Artistic Property, 72 HARv. L. Rev. 1079 (1959); Note, 68 Harv. L. REv. 349 (1954); Note, 108 U. PA. L. REv. 699 (1960).

20 Kalodner \& Vance, The Relation Between Federal and State Protection of Literary and Artistic Property, 72 HARv. L. REv. 1079, 1082-84 (1959). 
government was not reached by Marshall in Gibbons $v$. Ogden, ${ }^{21}$ but in the earlier state case, Livingston $v$. Van Inger, ${ }^{22}$ the same issues were presented and resolved in favor of state competence.

A state cannot take away from an individual his patent right, and render it common to all the citizens. This would contravene the Act of Congress, and would be, therefore, unlawful. But if an author or inventor, instead of resorting to the Act of Congress, should apply instead to the Legislature of this state for an exclusive right to his production, I see nothing to hinder the State from granting it, and the operation of the grant would, of course, be confined to the limits of this State. Within our own jurisdiction, it would be complete and perfect. So a patentee under the Act of Congress may have the time of his monopoly extended by the legislature of any state, beyond the term ... allowed by that law. Congress may secure for a limited time an exclusive right throughout the Union; but there is nothing in the Constitution to take away from the states the power to enlarge the privilege within their respective jurisdictions. ${ }^{23}$

Thus, the argument that the patent clause is a grant of exclusive power to Congress, preempting state law, has the burden of adverse precedent to sustain. But a similar result may be reached through the operation of the supremacy clause in instances where state law conflicts with the patent policy expressed in federal legislation.

Justice Black's invocation of federal patent policy to avoid state unfair competition law is not without precedent, although the earlier cases did not use the language of preemption. In Coats $v$. Merric Thread Co., ${ }^{24}$ plaintiff sued to enjoin defendant for trademark infringement and unfair competition in simulating the labels and symbols used by the plaintiff upon the ends of wooden sewing spools. In 1870 plaintiff's assignor had obtained a design patent for the design embossing the end of the sewing spool. The patent expired in 1877 , but prior to that time plaintiff registered as a trademark matter which was part of the subject matter of the patent. The Court conceded that "irrespective of the technical question of trade-mark, the defendants have no right to dress their goods up in such a manner as to deceive an intending purchaser and induce him to believe he is buying those of the plaintiff."25 The

2122 U.S. (9 Wheat.) 1 (1824).

229 N.Y. 507 (1812).

23 Id. at 581 (opinion of Kent, C.J.). Kent's opinion was described as entitled to great veight in Patterson v. Kentucky, 97 U.S. 501, 50809 (1878).

24149 U.S. 562 (1893). See Holzapfel's Compositions Co. v. Rahtjen's American Composition Co., 183 U.S. 1 (1901).

25149 U.S. at 566. 
Court nevertheless ruled that "plaintiff's right to the use of the embossed periphery expired with their patent, and the public had the same right to make use of it as if it had never been patented." 26 The inference is plain that the Court considered the patent monopoly as an exception to a general policy of competition, and that promotion of the arts and sciences would best be served by permitting only a conditional monopoly, the benefits of which would ultimately inure to the public.

This rationale was made explicit in Singer Mfg. Co. v. June Mfg. Co.27

It is self evident that on the expiration of a patent the monopoly created by it ceases to exist, and the right to make the thing formerly covered by the patent becomes public property. It is upon this condition that the patent is granted. It follows, as a matter of course, that on the termination of the patent there passes to the public the right to make the machine in the form in which it was constructed during the patent. ${ }^{28}$

These cases, and similar decisions in the lower courts, ${ }^{29}$ although not explicitly invoking federal preemption, foreshadowed the Compco and Stiffel decisions by setting forth a federal policy of freedom to use product features that was restricted only by the limited monopoly deemed necessary to "promote the arts and sciences," and the duty to identify competing products. ${ }^{30}$

Federal-state accommodation in the area of copyright perhaps suggests a similar policy. The first dictum one meets in investigating the relationship of common law copyright to statutory copyright is that they are mutually exclusive. While a persuasive case can be made that no question is more open than whether a statutory copyright operates to

26149 U.S. at 572.

27163 U.S. 169 (1896).

$28 \mathrm{Id}$. at 185.

29 See West Point Mfg. Co. v. Detroit Stamping Co., 222 F.2d 581 (6th Cir.), cert. denied, 350 U.S. 840 (1955); Zippo Mfg. Co. v. Rogers Imports, Inc., 216 F. Supp. 670 (S.D.N.Y. 1963); Zippo Mfg. Co. v. Manners Jewelers, Inc., 180 F. Supp. 845 (E.D. La. 1960).

30 A similar policy may perhaps be found in Morton Salt Co. v. G. S. Suppiger Co., 314 U.S. 488 (1942). There an action was brought in equity for patent infringement and the defense was interposed that the plaintiff by requiring purchasers of its patented machine to use its unpatented articles in operating the machines had restrained sale of the unpatented articles in violation of the Clayton Act. The Court affrmed dismissal of the complaint on the grounds of the public interest in competition which it said were found in a strict limitation of the patent grant; this conclusion enabled the Court to avoid deciding whether the Clayton Act had been violated. Strictly read, however, the opinion deals only with the limitation upon equity powers imposed by the public interest and it does not reach the question of whether federal policy requires preemption of state power. See also Scott Paper Co. v. Marcalus Mfg. Co., 326 U.S. 249 (1945). 
divest a party of his common law right, ${ }^{31}$ it is nevertheless generally conceded that rightly or wrongly, American law is settled that the common law right is extinguished when the federal one is applicable. Thus, in Holmes v. Hurst, ${ }^{32}$ the Supreme Court said, "it seems now to be considered the settled law of this country and England that the right of an author to a monopoly of his publications is measured and determined by the copyright act-in other words, that while a right did exist by common law, it has been superseded by statute." 33

The federal act is thus seen as pre-empting state law, but only partially, for the state common law copyright theoretically retains vitality for the period prior to the time statutory protection becomes available. ${ }^{34}$ This federal pre-emption begins when publication occurs. ${ }^{35}$ Thus publication of a copyrightable work without complying with the statutory formalities places the work in the public domain. In addition, publication of a work which is not copyrightable under the federal act but which is a writing within the meaning of the Constitution, and thus within Congress' reach under the patent clause, is seen as a forfeiture of the common law copyright in the work. ${ }^{36}$ Finally, publication of matter which has insufficient attributes to meet the Constitutional standard of "writings" 37 is also said to dedicate the common law right in such matter. ${ }^{38}$ Under copyright principles, therefore, the Day-Brite and Stiffel configurations would have been dedicated to the public at publication and, subject to possible federal protection, made free to the public. ${ }^{39}$

31 See Whicher, The Ghost of Donaldson v. Beckett: An Inquiry into the Constitutional Distribution of Powers Over the Law of Literary Property in the United States, 9 COPYRIGHT SOC. BULL. 102, 105-10, 194 (1962).

32174 U.S. 82,85 (1899).

33 Ibid.

34 That common law copyright protection of unpublished works is available is made explicit in $\S 2$ of the present Copyright Act. 61 Stat. 654 (1947), 17 U.S.C. $\S 2$ (1958).

35 G. Ricordi \& Co. v. Haendler, 194 F.2d 914 (2d Cir. 1952); National Comics Publications, Inc. v. Fawcett Publications, 191 F.2d 594 (2d Cir. 1951), clarified, 198 F.2d 927 (2d Cir. 1952); Fashion Originators' Guild v. FTC, 114 F.2d 80, 83 (2d Cir. 1940), aff'd, 312 U.S. 457 (1941).

36 RCA Mfg. Co. v. Whiteman, 114 F.2d 86, 89 (2d Cir.), cert. denied, 311 U.S. 712 (1940). But cf. Capitol Records v. Mercury Records Corp., 221 F.2d 657 (2d Cir. 1955).

37 Common examples are time cards, diaries, report forms, graph paper, account books, checks, score cards, order forms, vouchers, etc. See LATMAn, Howell's CopYrigrt LAW 38 (rev, ed. 1962).

38 G. Ricordi \& Co. v. Haendler, 194 F.2d 914 (2d Cir. 1952).

39 The suggestion that the Stiffel pole lamp might have been eligible for copyright protection is not too extreme, for both "writings" and "author" have been construed liberally. An author is essentially one who creates a work without copying. See Alfred Bell \& Co. v. Catalda Fine Arts, 191 F.2d 99, 102 (2d Cir. 1951), while writings include statuettes used as lamp bases in lamps sold for home use, Mazer v. Stein, 347 U.S. 201 
The copyright practice seems roughly similar to what the Court in Compco and Stiffel said was required by patent policy in design patent cases. The Court ruled that state protection was precluded by the possibility of federal protection and that matter, upon becoming eligible for such protection, fell into the public domain, subject to any statutory rights received by the owner or inventor.

Similarly the subject matter of a patent grant is assumed to become part of the public domain at the time of the grant, ${ }^{40}$ and matter ineligible for patent protection ${ }^{41}$ because exploited as a trade secret, ${ }^{42}$ or disclosed but not claimed in a patent application, ${ }^{43}$ is regarded as in the public domain from the time of first public use. Thus, in Compco and Stiffel, where the configurations were the very matter claimed as protected by the grant, the federal policy of relying on dedication "to promote the progress of science and useful arts" quite clearly applied. The configurations in Compco and Stiffel were dedicated to the public use by the grant of design patent protection, subject to a limitation on the public right during the life of the grant-a limitation terminated by the district court in both cases.

Federal policy thus seems to require at the least that all exploited "writings" and "discoveries" find protection under the federal statute or go unprotected, 44 yet in the past commercially exploited works have received some protection from common law copyright principles.

State competence to define publication has not been successfully challenged. ${ }^{45}$ By indulging in fictions, states have protected some commer-

(1954), textile fabrics used in dresses, Peter Pan Fabrics v. Martin Weiner Corp., 274 F.2d 487 (2d Cir. 1960), and junk jewelry, Boucher v. Du Boyes, Inc., 253 F.2d 948 (2d Cir.), cert. denied, 357 U.S. 936 (1958). See also Royalty Designs, Inc. v. Thrifticheck Serv. Corp., 204 F. Supp. 702 (S.D.N.Y. 1962); Dan Kasoff, Inc. v. Gresco Jewelry Co., 204 F. Supp. 694 (S.D.N.Y.), aff'd, 308 F.2d 806 (2d Cir. 1962).

40 Schriber-Schroth Co. v. Cleveland Trust Co., 305 U.S. 47, 57 (1938).

41 Pennock v. Dialogue, 27 U.S. (2 Pet.) 1, 23 (1829).

42 Ibid. See Macbeth-Evans Glass Co. v. General Elec. Co., 246 Fed. 695 (6th Cir. 1917), cert. denied, 246 U.S. 659 (1918).

43 Schriber-Schroth Co. v. Cleveland Trust Co., supra note 40.

44 The proposed revised Copyright Act is in accord with this policy. Section 19 provides that "all rights in the nature of copyright in works that come within the subject matter of copyright as specified by sections 1 and $2, \ldots$ whether published or unpublished, are governed exclusively by this title." The states are expressly forbidden to grant equivalent protection. But $\S 19$ (b) saves state power to protect rights "that are not equivalent to any of the exclusive rights within the general scope of copyright" as defined by the act, and "deceptive trade practices such as passing off and false representation" are enumerated as being within the scope of state competence. S. 3008, 88th Cong., 2d Sess. July 20, 1964.

45 Capitol Records v. Mercury Records Corp., 221 F.2d 657, 667 (2d Cir. 1955) (L. Hand, J., dissenting). 
cially exploited works. ${ }^{46}$ In Ferris $v$. Frohman, ${ }^{47}$ the Supreme Court recognized that the public performance of a play, no matter how often given or how great the number of viewers, is not such a publication of the play as to deprive the owner of his common law right to protection against appropriation by others. Later, in Waring $v$. WDAS Broadcasting Station, Inc. 48 the Supreme Court of Pennsylvania held that the sale of large numbers of phonograph records to the public with an express notice that the use of records purchased was "not licensed for radio broadcast" was not such a publication as would give the public a right to use the records so restricted in a radio broadcast. And in Metropolitan Opera Ass'n v. Wagner-Nichols Recorder Corp.,49 the New York state courts held that the performance of an opera in an opera house and its broadcast over a radio network did not constitute such a publication as forfeited the plaintiff's rights in the performance, and defendant was enjoined from recording the broadcast and making and selling phonograph records from the recording. More recently, in Ettore v. Philco Television Broadcasting Corp., ${ }^{50}$ the Third Circuit, applying the law of four states, held that in each state a plaintiff who performed in a boxing match with heavyweight champion Joe Louis in 1936 and who sold his movie rights in the "performance" nevertheless retained a right to exclude others from later showing film clips of the fight on television. Boxer Ettore, though consenting that all might see his fight either in the arena or on film, nevertheless was said to have retained a property right in his performance which was not dedicated to the public.

Perhaps the best explanation of this manipulation of the concept of publication is that the courts have been willing to indulge the states in order to avoid the inadequacies of the federal copyright scheme. ${ }^{51}$

46 " $[T]$ he courts apply different tests of publication depending on whether plaintiff is claiming protection because he did not publish and hence has a common law claim of infringement, in which case the distribution must be quite large to constitute 'publication' - r whether he is claiming under the copyright statute-in which case the requirements for publication are quite narrow. In each case the courts appear so to treat the concept of publication as to prevent piracy." American Visuals Corp. v. Holland, 239 F.2d 740 (2d Cir. 1956) (Frank, J.). See Kaplan, Publication in Copyright Law: The Question of Phonograph Records, 103 U. PA. L. REv. 469, 479-84 (1955), and Kalodner \& Vance, supra note 20, at 1093-95.

47223 U.S. 424, 435 (1912). See Uproar Co. v. National Broadcasting Co., 8 F. Supp. 356 (D. Mass. 1934), modified, 81 F.2d 373 (1st Cir. 1936).

48327 Pa. 433, 194 Atl. 631 (1937).

49199 Misc. 786, 101 N.Y.S.2d 483 (Sup. Ct. 1950), aff'd, 279 App. Div. 632, 107 N.Y.S.2d 795 (1951).

50229 F.2d 481 (3d Cir. 1956). See also Dior v. Milton, 9 Misc. 2d 425, 155 N.Y.S.2d 443 (Sup. Ct.), aff'd, 2 App. Div. 2d 878, 156 N.Y.S.2d 996 (1956).

51 See Kaplan, Publication in Copyright Law: The Question of Phonograph Records, 103 U. PA. L. REv. 469, 488 (1955); Note, 108 U. PA. L. Rev. 699 (1960). 
But the thrust of Compco and Stiffel seems to imply that the question of divestitive publication is to be controlled by federal law.52 Compco and Stiffel seem clearly to require that in cases where a state definition of publication conflicts with the federal copyright scheme, the state definition must give way; to allow the states to define publication, even in areas arguably not conflicting with the federal copyright policy, would produce the anomalous result of permitting a state definition in some cases while precluding it in others.

The question not reached by the patent dedication decisions, and involved in Compco and Stiffel, was whether matter which failed to qualify for protection under the federal statutes could be protected by the states. While the artificiality of the publication concept in the common law copyright cases suggests otherwise, the copyright cases are theoretically consistent with the patent policy of dedication. In extending the policy announced in the early patent dedication cases-that freedom of product use would be limited only when necessary to effectuate the federal policy of promoting science and the useful arts or when necessary to prevent fraud by requiring product identification-to matter failing to qualify for federal protection, Compco and Stiffel did little to articulate what state regulation might not be regarded as in conflict with the federal scheme.

In Sperry v. Florida ${ }^{53}$ the Supreme Court held that Florida was preempted from regulating the activities of a non-lawyer licensed by a federal agency to practice before the patent office, even though that person's activities amounted to the practice of law in Florida, where he was not licensed. The Court reasoned that establishing a patent office was clearly within Congress' express constitutional power to grant patents and that authorizing competent persons to assist in the administration of that office did not exceed what was necessary and proper. Florida, therefore, could not forbid as the unauthorized practice of the law what Congress had validly authorized under its patent power.

But that decision did not hold that the federal government had preempted the regulation of the unauthorized practice of law, nor did it hold that the patent agent involved could practice law in Florida, without being subject to Florida regulations, other than by preparing patent applications. Compco and Stiffel are analogous. Although holding that state unfair competition law cannot grant protection which conflicts with federal patent policy, the Court did not require pre-emption of all state protection.

The Supreme Court has often recognized the power of a state to

52 See note 44 supra.

53273 U.S. 379 (1963). 
regulate the plane of competition by prohibiting fraud ${ }^{54}$ and that which is deemed unfair, ${ }^{55}$ and by legislating under the police power. ${ }^{56}$

State unfair competition law has been the source of protection for many forms of product differentiation ranging from configurations to trademarks and tradenames. ${ }^{57}$ The federal courts, in hearing cases in unfair competition under their pendent jurisdiction, ${ }^{58}$ have assumed unfair competition doctrine to be a matter of state law. ${ }^{59}$ Consequently, the results in Compco and Stiffel suggest that pre-emption was invoked by the Court as the only means available to federal courts to arrest certain developments in state unfair competition law; the decisions can be explained as being consistent with traditional notions of protection against "passing off," while impliedly rejecting the "misappropriation" theory and extension of technical trademark protection to cases of product simulation.

Traditional unfair competition doctrine confers judicial protection upon product configurations not protected by a patent or a copyright only when the configuration is a source symbol to a substantial number of consumers in the relevant market. ${ }^{60}$ Only when consumers identify the nonfunctional features of a product with a particular source will unfair competition doctrine prevent a competitor from copying those features, and benefiting from the resultant consumer confusion. The standard was set forth in strict terms by Learned Hand in Crescent

54 See Allen v. Riley, 203 U.S. 347, 355 (1906).

55 See Pecheur Lozenge Co. v. National Candy Co., 315 U.S. 666 (1942); Fashion Originators' Guild v. FTC, 312 U.S. 457, 468 (1941); A.L.A. Schechter Poultry Corp. v. United States, 295 U.S. 495, 531-32 (1935); Hurn v. Oursler, 289 U.S. 238 (1933). See also Ferris v. Frohman, 223 U.S. 424 (1912).

56 "[T]he right conferred upon the patentee ... to use and vend ... must be exercised in subordination to the police regulations which the state . . established." Patterson v. Kentucky, 97 U.S. 501, 505 (1878).

57 See generally Chafee, Unfair Competition, 53 Harv. L. REv. 1289 (1940); Rahl, The Right to "Appropriate" Trade Values, 23 OHo Sr. L.J. 56 (1962); Stern \& Hoffman, Public Injury and the Public Interest: Secondary Meaning in the Law of Unfair Competition, 110 U. PA. L. REv. 935 (1962); Developments in the Law-Competitive Torts, 77 HARv. L. Rev. 888 (1964); Developments in the Law-Trade-Marks and Unfair Competition, 68 Harv. L. Rev. 814 (1955); Note, 77 HARv. L. Rev. 520 (1964); Note, 73 Yale L.J. 389 (1964); Comment, 29 U. CHI. L. Rev. 371 (1962).

5828 U.S.C. $\S 1338$ (b) (1958).

59 E.g., Maternally Yours v. Your Maternity Shop, 234 F.2d 538 (2d Cir. 1956). The Ninth Gircuit is contra. Neal v. Thomas Organ Co., 325 F.2d 978 (9th Cir. 1963); Bliss v. Gotham Industries, Inc., 316 F.2d 848 (9th Cir. 1963). See also Federal-Mogul-Bower Bearings, Inc. v. Azoff, 313 F.2d 405 (6th Cir. 1963) (federal remedy for unfair competition in 43(a) of the Lanham Act).

60 E.g., Zippo Mfg. v. Rogers Imports, Inc., 216 F. Supp. 670 (S.D.N.Y. 1963). See authorities cited supra note 57. 
Tool v. Kilborn \& Bishop Co.61 "The plaintiff . . . [must] . . show that the appearance of his wares has in fact come to mean that some particular person ... makes them, and that the public cares who does make them, and not merely for their appearance and general structure." 62 In short, this aspect of unfair competition doctrine recognizes that otherwise unprotected features of goods should be free to competitors, but restrains that freedom when necessary to protect the source associations of consumers.

The law of source symbols, whether marks or configurations, can be found in the first trademark case decided by the Supreme Court, Delaware of Hudson Canal Co. $v$. Clark. ${ }^{63}$ The question in that case was whether the plaintiff had an exclusive right to use the words "Lackawanna Coal" to designate coal mined by plaintiff and transported over its railroad to market. The Court refused to find mark rights in what it regarded as a term geographically descriptive of the product to which it was applied. It acknowledged that rights in trademarks were unlike rights in things protected by patent or copyrights in that words and symbols in common use-in the public domain - could be adopted and an exclusive right in their use as a mark obtained, because marks in themselves had no utility other than to give notice who was the producer of a particular article. There were limitations, the court noted, in that "no one can claim protection for the exclusive use of a trademark or trade name which would practically give him a monopoly in the sale of any goods other than those produced or made by himself. If he could, the public would be injured rather than protected, for competition would be destroyed." 64 Otherwise, said the court, if a mark does not have this latter quality and does indicate origin, it will be protected against appropriation by a competitor, on the theory that in a competitive economy no man has a right to sell his goods as another's.

The teaching of that opinion can be illustrated in a series of examples. $A$ and $B$ are competitors. $C$ enters $A$ 's store. $A$ offers $C$ article $X$ telling him $B$ is the source, and $C$ buys. Assume $C$ never heard of $B$ and did not care about source. $B$ has a cause of action against $A$ for passing off A's product as B's. ${ }^{65}$

Suppose a similar set of facts. A and B are competitors. B marks his product with a $\mathrm{Z}$ in such a way that the $\mathrm{Z}$ qualifies as a technical trade-

61247 Fed. 299 (2d Cir. 1917).

62 Id. at 300.

6380 U.S. (13 Wall.) 311 (1872). See McLean v. Fleming, 96 U.S. 245 (1878); TradeMark Cases, 100 U.S. 82 (1879).

6480 U.S. (13 Wall.) 311, 323 (1872).

65 Thomson v. Winchester, 36 Mass. (19 Pick.) 214 (1837). 
mark. $\mathrm{C}$ enters A's store and buys an article $\mathrm{X}$ marked with a $\mathrm{Z}$. Article $X$ was made by $A$. A said nothing to $C$. $C$ never heard of $B$ and never saw the mark $Z$. B has a cause of action against A for passing off A's product as B's. ${ }^{68}$ If $B$ wishes, he may refer to $A$ 's conduct as either passing off or trademark infringement.

Take another case. A and B are competitors. B begins selling his product in pinch bottles. $A$ is at once attracted by the package and puts up his product in a pinch bottle. $\mathrm{C}$ enters $\mathrm{A}$ 's store and buys product $\mathrm{X}$ in a pinch bottle. Product $\mathrm{X}$ was made by $\mathrm{A}$. $\mathrm{B}$ has no cause of action against $A$. A has not passed off his product as B's because he neither said A's product is B's nor used B's technical trademark on A's product, which in the law is the same as saying $A$ 's product is $B^{\prime}{ }^{6} .{ }^{67} \mathrm{~A}$ merely copied B's marketing scheme using a bottle configuration which was in the public domain.

Now, vary the last case. $A$ and $B$ are competitors. $B$ has sold his product in a pinch bottle for many years with the result that a large percentage of consumers identify a desired source by the pinch bottle in which a product is marketed. $G$ walks into A's store and buys product $X$, packaged in a pinch bottle. Product $X$ was made by $A$. $B$ has a cause of action against $A$ for passing off A's product as B's. ${ }^{68}$ Although $B$ may have to complain about A's unfair competition rather than A's passing off, the case is similar to the first and second hypotheticals. By confronting $\mathrm{C}$ with product $\mathrm{X}$ in a pinch bottle, $\mathrm{A}$ was in effect saying " $\mathrm{B}$ made this," just as if he mouthed the words or used B's technical trademark.

Suppose that, in the last example, instead of a pinch bottle what was involved was the shape of the product itself, and suppose that the shape contributed to the usefulness of the product. Assume that the shape had been used exclusively by $B$ in such a way that it became a source symbol. $B$ will be unable to gain effective relief against $A$, for here $B$ is claiming protection for the exclusive use of a source symbol which would, in the terms of the first Supreme Court trademark pronouncement, give him a monopoly in the sale of particular utilitarian features. ${ }^{68}$

In the latter case state trademark law, or more broadly, unfair competition law, would refuse to treat as a trademark a use of features of goods which would confer rights like patent rights.70 And this is what

66 Dean v. Steel, Latch 188, 82 Eng. Rep. 339 (K.B. 1625); Southern v. How, Popharn 143, 144, 79 Eng. Rep. 1243, 1244 (K.B. 1617).

67 Hygienic Specialties Co. v. H. G. Salzman, Inc., 302 F.2d 614 (2d Cir. 1962).

68 J. N. Collins Co. v. F. M. Paist Co., 14 F.2d 614 (E.D. Pa. 1926).

68 Zippo Mfg. Co. v. Rogers Imports, Inc., 216 F. Supp. 670 (S.D.N.Y. 1963).

70 State unfair competition law has always excluded from protection on unfair com- 
- happened in Compco and Stiffel, except that the fixture configurations involved were not in fact performing a trademark function, and except that federal law rather than state law was invoked to refuse protection to the fixtures.

Although the appellate court in Stiffel sought to interpret the trial court's findings of customer confusion as referring to the source of the lamps, ${ }^{71}$ it seems clear that the district court did no more than find that the Sears lamp was confusingly similar in appearance to the Stiffel lamp. That consumers would confuse the two products does not suggest that consumers associated either lamp with a particular source, a necessary finding under traditional theory.

Similarly, the plaintiff did not show nor did the lower courts find a protectable source symbol in the Compco case. The district court did not find that buyers associated the reflector design with Daybrite as a source. It was only found that the design had the capacity to identify Daybrite to the trade and did in fact so identify plaintiff, and that the reflectors were confusingly similar. ${ }^{72}$ But it is existing consumer source associations that are given preference in unfair competition, not distributor's associations or future consumer's associations. The mental processes of persons who are not consumers, ${ }^{73}$ of persons who are not in the market, ${ }^{74}$ and of persons who are not in the relevant market ${ }^{75}$ have all been held to be improper measures of whether a particular feature is a source symbol. Only the source associations of consumers in the market place take precedence over a manufacturer's right to copy anything not protected by one of the statutory monopolies. Concern for the source associations of people in the trade cannot override the consumer's right to the benefits of competition. Accordingly, as a matter of unfair competition law, Compco and Stiffel are consistent with traditional theories controlling "passing off"-no consumer source associations were found

petition features of goods which were functional according to state law. See Speedry Prods., Inc. v. Dri Mark Prods., Inc., 271 F.2d 646 (2d Cir. 1959).

71 Stiffel Co. v. Sears Roebuck \& Co., 313 F.2d 115, 118 n.6 (7th Gir. 1963), rev'd, 376 U.S. 225 (1964).

72 Brief for the United States as Amicus Curiae, pp. 38-39, Compco Corp. v. DayBrite Lighting, Inc., 376 U.S. 234 (1964). Apparently the only evidence on the issue of source association was testimony of the employees of the parties who generally described the contested reflector design as distinctive. Brief for Petitioner, p. 15, Compco Corp. v. Day-Brite Lighting, Inc., supra.

73 O'Day Corp. v. Talman Corp., 310 F.2d 623, 625 (1st Cir. 1962), cert. denied, 372 U.S. 977 (1963).

74 Airstream Trailers, Inc. v. Cayo, 221 F. Supp. 557, 558 (D.W. Mich. 1963).

75 American Luggage Works, Inc. v. U.S. Trunk Co., 158 F. Supp. 50 (D. Mass. 1957), aff'd sub. nom. Hawley Prods. Co. v. U.S. Trunk Co., 259 F.2d 69 (Ist Cir. 1958). See Elastic Stop Nut Corp. v. Alexander Flasher Corp., 137 U.S.P.Q. 205 (D. Mass. 1963). 
to be present and the products' features were not found to be nonutilitarian.

The "misappropriation" cases, usually thought to add a new dimension to the law of unfair competition, can be regarded as in conflict with the Compco and Stiffel results. These cases have given protection to a variety of types of "intellectual property" against appropriating competitors despite the absence of patent, copyright or trademark protection. The most famous is the Associated Press case, ${ }^{76}$ decided as a matter of federal common law prior to Erie v. Tompkins.77 The Supreme Court, while assuming that Associated Press had no property interest in uncopyrighted news matter published in newspapers or posted on bulletin boards, held it could nevertheless exclude International News Service from using those sources for news which INS distributed as its own while operating a rival service. The Court's opinion was cast in sweeping language, reasoning that INS should be enjoined, not because it had copied plaintiff's product, but because it had taken something that was the product of plaintiff's "labor, skill and money." Read liberally, the logic supports protection against any competition by similar products where it can be shown that the originator has invested something of value in the development of his product.

Although never overruled, the precedent value of Associated Press today is doubtful. In Kellogg Co. v. National Biscuit Co., ${ }^{78}$ the Supreme Court was asked to protect the pillow-shaped form for a shredded wheat biscuit against use by a rival cereal manufacturer. It refused, saying that the precise form of the biscuit was dedicated to the public by the termination of plaintiff's patents. National Biscuit Co. alleged unfair competition on a theory reminiscent of the previously decided Associated Press case. The Court's reasoning was clear. Since the expiration of the patent monopoly conferred upon the public the right to make the thing formerly covered by the patent, no party may assert exclusive rights in that subject matter. ${ }^{79}$ The only duty of the defendant was "to identify its product lest it be mistaken for that of the plaintiff." 80 In language seemingly directed to the Associated Press opinion, although not citing it, the Court rejected the argument that the defendant had unfairly appropriated plaintiff's work product.

76 International News Service v. Associated Press, 248 U.S. 215 (1918). Gf. Reichelderfer v. Quinn, 287 U.S. 315 (1932); The Fire-Extinguisher Case, 21 Fed. 40 (C.C.D. Md. 1884).

77304 U.S. 64 (1938).

78305 U.S. 111 (1938).

79 Id. at 120.

80 Ibid. 
Kellogg Company is undoubtedly sharing in the goodwill of the article known as "Shredded Wheat"; and thus is sharing in a market which was created by the skill and judgment of plaintiff's predecessor and has been widely extended by vast expenditures in advertising persistently made. But that is not unfair. Sharing in the goodwill of an article unprotected by patent or trade-mark is the exercise of a right possessed by all-and in the free exercise of which the consuming public is deeply interested. ${ }^{81}$

Kellogg may easily be read as strictly limiting the theory of Associated Press. Although since Erie the Supreme Court is theoretically incapable of expressly overruling Associated Press, Kellogg and other indications of disapproval 82 suggested that the "misappropriation" rationale was to be severely restricted. Compco and Stiffel can be regarded as marking the doctrine's final demise.

But some infusion of the misappropriation theory can be detected in cases decided ostensibly on traditional unfair competition grounds ${ }^{83}$ by courts desiring to avoid the requirement of source association, but reluctant to rest their decision expressly upon misappropriation doctrine. ${ }^{84}$

Flint v. Oleet Jewelry Mfg. Co. ${ }^{85}$ and Mastercrafters Clock \& Radio Co. v. Valcheron \& Constant-Le Coultre Watches, Inc. ${ }^{86}$ are illustrative. The facts resemble the Associated Press situation. In Flint the court enjoined defendant's sale of a mustard seed charm substantially similar to plaintiff's. In Mastercrafters, the court enjoined the clock and radio

81305 U.S. at 122.

82 E.g., Cheney Bros. v. Doris Silk Corp., 35 F.2d 279 (2d Cir. 1929), cert. denied, 281 U.S. 728 (1930). In Fashion Originators' Guild of America v. Federal Trade Comm'n, 312 U.S. 457 (1941), the Court stated that the principles declared in Associated Press could not legalize a combination which violated the Sherman Act. The question there was whether an association of members of the garment industry could resort to self help in order to reduce competition presented by pirated dress designs. The Court found the combination illegal and refused to consider whether the alleged practices sought to be eliminated were tortious, contending that even if the pirating were tortious it could not justify the combination. Thus, the Court did not expressly disavow the misappropriation theory of Associated Press, but by refusing to allow that case to be used in defense of an anti-trust action the Court indicated that a policy of competition was the paramount interest to be preserved. Cf. Millinery Creator's Guild v. Federal Trade Comm'n, 312 U.S. 469 (1941).

83 See Rushmore v. Manhattan Screw \& Stamping Works, 163 Fed. 939 (2d Cir. 1908); Yale \& Towne Mfg. Co. v. Alder, 154 Fed. 37 (2d Cir. 1907); Enterprise Mfg. Co. v. Landers, Frary \& Clark, 131 Fed. 240 (2d Cir. 1904).

84 Day-Brite Lighting, Inc. v. Compco Corp., 311 F.2d 26, (7th Cir. 1962), rev'd, 376 U.S. 234 (1964), is an excellent example.

85133 F. Supp. 459 (S.D.N.Y. 1955).

86221 F.2d 464 (2d Cir.), cert. denied, 350 U.S. 832 (1955). 
company from distributing clocks similar in appearance to those distribute by Valcheron. Although both results seemingly depend upon a "misappropriation" theory, the decisions were based instead upon findings of customer and non-customer confusion or the probability of such confusion. These and other recent unfair competition decisions, ${ }^{87}$ like the misappropriation cases, assume that the probable confusion resulting from product similarity encroaches upon a public interest important enough to justify conferring a monopoly power upon the originator without reference to consumer source associations. ${ }^{88}$ Compco and Stiffel will certainly retard such developments.

Compco and Stiffel portend an even more direct impact upon state law. The decisions teach that certain product features, like pole lamp configurations, are protectable only under the federal statutes or not at all, without regard to possible source associations. In terms of traditional unfair competition doctrine, whether certain product features are functional and therefore unprotectable even as source symbols is now a matter of federal policy.89 Unfortunately, the Compco and Stiffel decisions themselves offer scant assistance in defining "federal functionality."

Thus the decisions in Compco and Stiffel can be read as a return to traditional principles of unfair competition law.90 The policy announced in the early patent cases of freedom to use product features otherwise unprotected by patent, copyright or trademark law was reaffirmed. By expressly recognizing the state interest in promoting product identification, Compco and Stiffel saved to the states their traditional area of, competence; but by resting on preemption grounds, the decisions ensured that state protection could not be the basis for acquiring monopoly powers similar to those conferred by the federal statutes.

87 E.g., Mercury Record Corp. v. Buckingham Record Co., 226 F. Supp. 427 (S.D.N.Y. 1963); Audio Fidelity, Inc. v. High Fidelity Recordings, Inc., 283 F.2d 551 (9th Cir. 1960), cert. denied, 371 U.S. 934 (1962).

$88 \mathrm{Cf}$. the development in the law of trademarks and tradenames. Comment, 29 U. Ghr. L. Rev. 371 (1962); Note, 77 HaRv. L. Rev, 520 (1964). The Court in Stiffel suggested that the analogy from trademark and tradename protection to cases of product simulation may have been hasty. 376 U.S. at $227 \mathrm{n} .2$ (1964). For a possible basis of distinguishing the trademark and tradename cases, see Note, 73 YALE L.J. 389 (1964) (discussing the Compco and Stiffel decisions in the Seventh Circuit).

89 The minimum aspects of functionality would be defined by federal policy, but state law would not, of course, be precluded from enlarging the definition to embrace more than is required by federal law.

90 See Note, 73 Yale L.J. 389 (1964). 